\title{
Rescue medical activities among sea migrants and refugees in the Mediterranean region: lessons to be learned from the 2014-2020 period
}

\author{
Polyxeni Theodosopoulou ${ }^{1}$, Costas Tsiamis $^{2}$, Andreas Pikoulis ${ }^{1}$, Anastasia Pikouli ${ }^{1}$, \\ Exadaktylos Aristomenis ${ }^{3}$, Emmanouel Pikoulis ${ }^{1}$
}

\author{
${ }^{1}$ Msc "Global Health and Disaster Medicine", Medical School, National and Kapodistrian University of Athens, Greece \\ ${ }^{2}$ Department of Public and One Health, School of Health Sciences, University of Thessaly, Larissa, Greece \\ ${ }^{3}$ Department of Emergency Medicine, Medical School University of Bern, Switzerland
}

\begin{abstract}
Background: Since 2014, the number of migrants and refugees crossing the Mediterranean towards Europe has risen significantly due to various reasons. Both state agencies and non-governmental organizations (NGOs) have launched rescue missions in the Central Mediterranean in accordance with international legal obligations for search and rescue (SAR) operations for those under distress at sea. Our aim is to summarise the specific qualifications needed for maritime SAR in the Mediterranean both in terms of the population at risk, the equipment and the medical support required, especially during the coronavirus disease 2019 (COVID-19) pandemic and the operational legal framework.

Materials and methods: This article aims to summarise the key points of SAR efforts from a medical perspective as depicted in the relevant literature during a specific timeline period (2014-2020) in a specific part of the Mediterranean Sea (Central Mediterranean route). Only papers published in English and whose full text was available were included in this study. The inclusion criteria were: a) articles referring to sea rescue operations between 2014 and 2020, b) research that focused on medical preparedness and assistance during rescue operations in the Central Mediterranean route, c) studies concerning demographic and clinical features of the rescue population, d) guidelines on the rule of conduct of persons and states participating in rescue activities. The exclusion criteria were: a) studies describing SAR operations in different regions of the world and b) studies focusing on routes, demographics and medical support of migrants/refugees on land.

Results: Three major themes were identified: a) characteristics of the population in distress at sea: country of origin, age groups, presence of communicable and non-communicable diseases were identified in the relevant literature. Our research shows that dermatological and respiratory issues were the major concerns among sea migrants, coming from different countries of both Africa and Asia, being relatively young and mostly males; $b$ ) medical preparedness and equipment needed for rescue: according to current guidelines, revised during the COVID-19 pandemic, infrastructure needed during SAR operations includes both equipment for resuscitation, personal protective equipment, deck adjustments, medical personnel trained to function in an austere setting and able to handle vulnerable patient groups such as children and pregnant women; c) medico-legal implications of SAR operations: knowledge of the legal framework encompassing SAR operations seems necessary, as European Union and state led initiatives seem to withdraw from proactive SAR, while criminalising NGO led rescue efforts. Operating with the imperative to save lives seems to be the only way of respecting international law and human values, thus, a summary of what the law dictates was made in an effort to keep medical workers participating in such operations updated.
\end{abstract}


Conclusions: Investigation aims to shed light on the special clinical features of sea migrants, the skills, equipment and organizational structure needed by medical workers participating in SAR operations as well as the legal framework under which they will be asked to operate. Special consideration will be given to the difficulties that emerged due to the COVD-19 pandemic.

(Int Marit Health 2021; 72, 2: 99-109)

Key words: sea migrants, search and rescue (SAR), Mediterranean route, initial assessment, COVID-19

\section{INTRODUCTION}

Migrants and refugees travelling by sea are not a phenomenon of the last decade; however, ongoing conflicts and war on several regions of the planet, including Northern Africa and Middle East, has provoked an unprecedented larger influx of people through different Mediterranean routes (West, Central and East Mediterranean route) between 2014 and 2020. Search and rescue (SAR) activities, established by European countries since the 70s, largely depend on national coast guard and rescue coordination centres (RCCs), European Union's border security agencies (FRONTEX), and vessels involving humanitarian agencies. Medical assistance provided during any SAR operation, no matter the agencies involved, requires previous knowledge of the demographic and clinical features of sea migrants, basic understanding of the medicolegal aspect of any rescue occurring at maritime environment, as well as skills on handling emergency medical situations up until delivery to a land-bound emergency service.

\section{STEPS TOWARDS RESCUE}

Usually as soon as a distress call gets intercepted, the RCC in charge of the relevant SAR zone is contacted. Even if the wrong RCC gets contacted, it remains the RCC's responsibility to transfer the case to the centre responsible for the region [1]. Afterwards the centre and the Government to which the region belongs falls under the obligation to coordinate the whole rescue effort either by sending state vessels, or any vessel they judge as capable of performing the operation at the time and to arrange for a safe disembarkation of those rescued (Fig. 1) [1-3].

The above description of current rescue efforts in the central Mediterranean migrational route, along with the fundamental legal obligations of those participating during such rescue operations and the organizational patterns implemented throughout an operation, seem to constitute a prerequisite knowledge for all the medical personnel involved, no matter the agency they choose to be employed by.

The aim of our study is to analyse the conditions upon which SAR operations were performed upon a specific time- line. Both the characteristics of the population at risk, the equipment, the medical qualifications and the legal restrictions concerning such operations will be mentioned. Special consideration will be given on the risks and difficulties that emerged due to the coronavirus disease 2019 (COVID-19) pandemic.

\section{METHODOLOGY}

The search was conducted through electronic databases including PUBMED and ScienceDirect. We used a series of logic combinations and research terms related to the topic including: "sea rescue", "SAR", "refugee rescue", "Mediterranean", "medical assistance". Only papers published in English and whose full text was available were included in this study. The inclusion criteria were: a) articles referring to sea rescue operations between 2014 and 2020, b) research that focused on medical preparedness and assistance during rescue operations in the Central Mediterranean route, c) studies concerning demographic and clinical features of the rescue population, d) guidelines on the rule of conduct of persons and states participating in rescue activities. The exclusion criteria were: a) studies describing SAR operations in different regions of the world, b) studies focusing on routes, demographics and medical support of migrants/refugees on land.

\section{DISCUSSION \\ AN OVERVIEW OF THE SITUATION}

Three different sea routes exist for migration in the Mediterranean: an Eastern one extending between Turkey and Greece, a Western one from North-West Africa up to Spain and a Central between North Africa, Malta and Italy. The Central route is the one receiving the largest influx of migration reaching 181,436 migrants during 2016 , the highest number ever recorded in the region [4]. The majority of arrivals, during our focus period, have shifted from people originating from Syria and Eritrea [5] before 2016 to people arriving from Sub-Saharan Africa and Maghreb countries as approaching 2020 . While the majority, throughout our timeline, consists of adult males, a large number of minors frequently unaccompanied is being observed both during 2014 with 12,000 unaccompanied minors arriving via the 


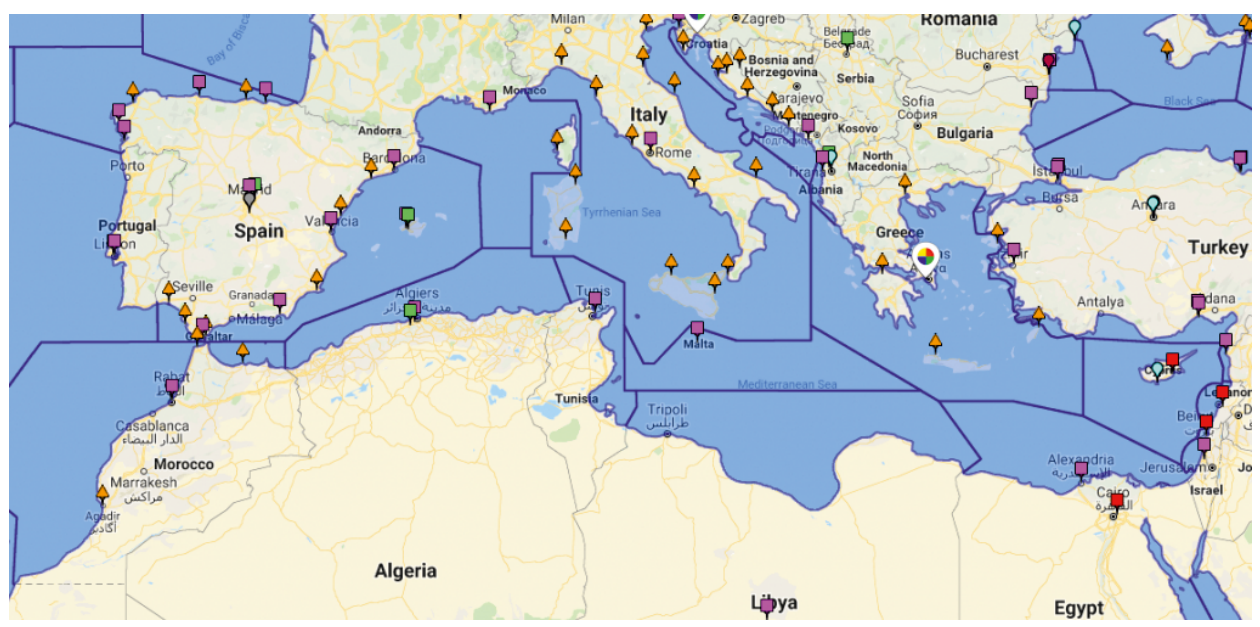

Figure 1. Map showing the Mediterranean search and rescue zones. Credit: Worldwide Search and Rescue contacts, managed by the Canadian Coastguard (Available from: https://www.infomigrants.net/en/post/18037/can-the-law-of-the-sea-regulate-the-stormystandoffs-between-private-rescue-ships-and-eu-governments)

Table 1. Mediterranean Sea arrivals of migrants (by UNCHR) and dead and missing persons (by the Missing Migrants Project of International Organization for Migration) between 2014 and 2020, data available from: https://data2.unhcr.org/en/situations/mediterranean and https://missingmigrants.iom.int/region/mediterranean?migrant_route $\% 5 \mathrm{~B} \% 5 \mathrm{D}=1376$

\begin{tabular}{lllll}
\hline Year & Arrivals total & $\begin{array}{l}\text { Dead and missing } \\
\text { total }\end{array}$ & $\begin{array}{l}\text { Arrivals } \\
\text { (central route) }\end{array}$ & $\begin{array}{l}\text { Dead and missing } \\
\text { (central route) }\end{array}$ \\
\hline 2014 & 225,445 & 3,320 & 170,100 & 3,165 \\
2015 & $1,032,408$ & 4,054 & 153,842 & 3,149 \\
2016 & 373,652 & 5,143 & 181,436 & 4,581 \\
2017 & 185,139 & 3,139 & 119,369 & 2,873 \\
2018 & 141,472 & 2,299 & 23,370 & 1,314 \\
2019 & 123,663 & 1,885 & 11,471 & 1,262 \\
2020 & 87,412 & 1,417 & 34,133 & 983
\end{tabular}

Central Mediterranean route and during 2020 with a total of 36,414 migrants arriving to Italy and Malta, $18 \%$ of which were children. The pattern of attempted sea crossings appears to be seasonal, with greater numbers observed during the summer months. At Table 1 we can see the trends of sea arrivals between 2014 and 2020, in the Mediterranean as a whole and specifically through the Central route, with data acquired from United Nations High Commissioner for Refugees (UNHCR) and the recorded deaths by the Missing Migrants Project of the International Organization for Migration (IOM) (Table 1).

As for 2021, while writing the present paper, IOM's Missing Migrants Projects recorded at least 237 deaths between January and March 2021.

It is worth mentioning that the vast majority of arrivals and unfortunately deaths, throughout the timeline that we investigate (2014-2020), are being observed mainly on the Central Mediterranean route. Data from the IOM (Table 2 [6]), clearly show higher death rates in the Central Mediterranean region, from the beginning of the investigated migration wave (2015) up until recently (2019). On Figure 2, we have an optical analogue of the surge of deaths and disappearances observed on the above mentioned region, leaving no doubt of the importance that the Central Mediterranean Sea holds when discussing search and rescue efforts.

One also has to underline the fact that, after the implementation of the European Union (EU)-Turkey cooperation in the field of migration during the spring of 2016, a great shift was observed from the East Mediterranean Sea route, between Greece and Turkey in the Aegean Sea, towards the Central route between Italy, Malta and Libya [7]. Such a gradual shift is clearly depicted on the following map by FRONTEX, regarding border crossings during 2020 (Fig. 3). While the Eastern route shows a $74 \%$ decrease in crossings, the Central route suffers a $137 \%$ increase, partly attributed to the EU-Turkey deal in 2016. 
Table 2. Death rates in the three Mediterranean routes, 2015-2019 (according to the International Organization for Migration and the International Organization for Migration's Global Migration Data Analysis Centre), data available from: https://publications.iom. int/system/files/pdf/mortality-rates.pdf

\begin{tabular}{lllll}
\hline Year & $\begin{array}{l}\text { Western } \\
\text { Mediterranean }\end{array}$ & $\begin{array}{l}\text { Central } \\
\text { Mediterranean }\end{array}$ & $\begin{array}{l}\text { Eastern } \\
\text { Mediterranean }\end{array}$ & $\begin{array}{l}\text { Total } \\
\text { (all three routes) }\end{array}$ \\
\hline 2015 & $0.62 \%$ & $1.98 \%$ & $0.08 \%$ & $0.36 \%$ \\
2016 & $0.87 \%$ & $2.27 \%$ & $0.21 \%$ & $1.20 \%$ \\
2017 & $0.77 \%$ & $1.98 \%$ & $0.12 \%$ & $1.41 \%$ \\
2018 & $1.23 \%$ & $2.88 \%$ & $0.29 \%$ & $1.34 \%$ \\
2019 & $1.67 \%$ & $4.78 \%$ & $0.05 \%$ & $0.99 \%$
\end{tabular}

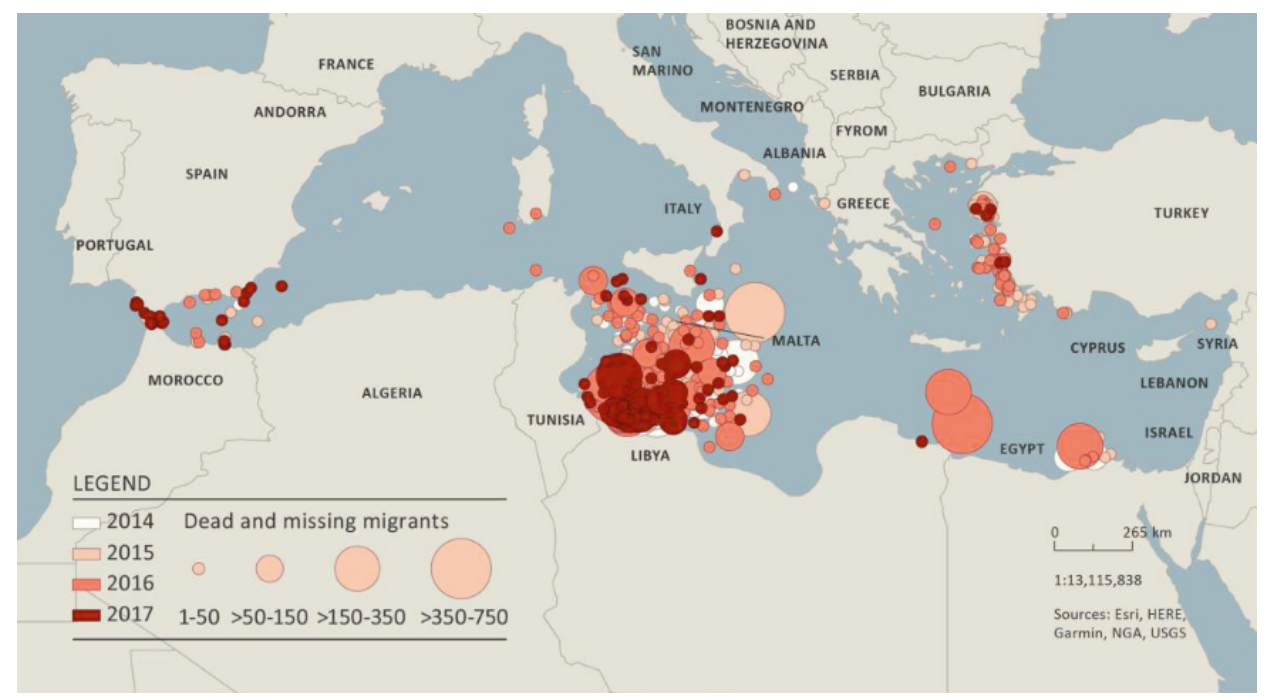

Figure 2. Migrant fatalities and disappearances recorded in the Mediterranean, 2017 (In: The Central Mediterranean route: Migrant Fatalities January 2014-July 2017, IOM's Global Migration Data Analysis Centre/UK Aid, Berlin 2017)

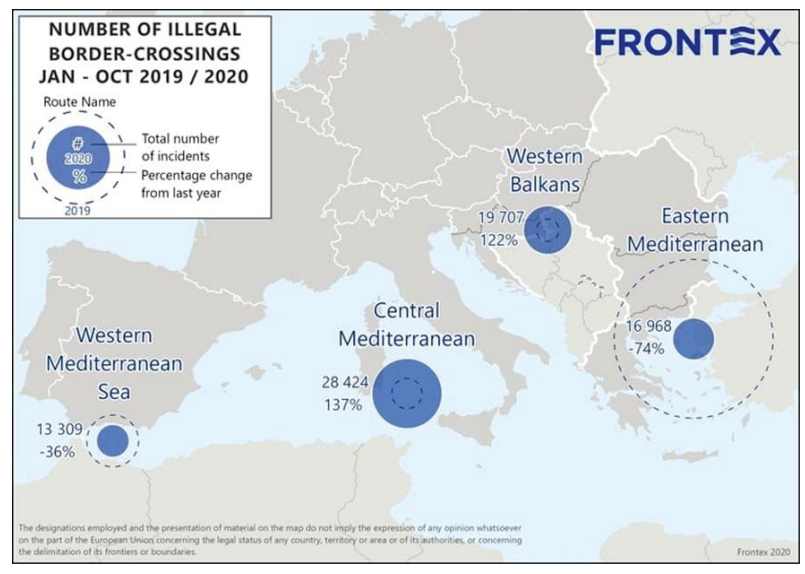

Figure 3. European Union Border Crossings between January and December 2020 (Map by Courtesy of FRONTEX, the European Border and Coast Guard Agency. Available from: https://frontex.europa.eu/media-centre/news/news-release/ irregular-migration-into-eu-last-year-lowest-since-2013-due-to-covid-19-j34zp2)

\section{A. THE PATIENT POPULATION IN DISTRESS AT SEA}

A study performed by Kulla et al. [8] presents data collected during 2015 by an EU-led military operation (EUNAVFORD MED, Operation SOPHIA). The study's population involved mostly adult males, with the second largest group being children. Only a small percentage required treatment, with $3 \%$ needing transportation to an emergency field hospital [8]. Similar findings are presented by Escobio et al. [9] during 2016 in an operation organized by SOS Mediterranée and Médecins du Monde (MdM) on the boat Aquarius, although a higher percentage of unaccompanied male minors mainly from Sub-Saharan Africa were encountered [9]. Trovato et al. [10] performing their study at a disembarkation point in Sicily during 2014 note the existence of two different population groups in terms of demographic and clinical conditions: one with migrants from Near East with larger percentages of vulnerable groups (children, women, elderly, disabled), major chronic 
conditions and health-seeking behavioural patterns and one with mostly young male Africans with high numbers of unaccompanied minors [10]. However all three studies share common ground on the conditions affecting the population at risk during SAR operations. Physical exhaustion, malnutrition and lack of fluids along with dermatological (chemical burns, scabies), respiratory (infection), gastrointestinal (pain, diarrhoea) conditions and trauma (accidental and intentional) constituted the main entities the medical personnel had to confront [8-10]. Suffering from traumatic events, including witnessing people drowning and being exposed to violence contributed to a heavy psychological burden in such populations resulting some times in medically unexplained physical symptoms [9]. The concern for communicable diseases seems to be impractical both due to their low prevalence in the provenance of the refugees, the lack of vectors to transmit tropical diseases during the trip and the fact that a previous long journey through the Sahara surpasses the incubation period of several viral or bacterial infections $[2,10]$. More specific fourth study gathering information from children arriving in Spain through the West Mediterranean route ends up in similar findings regarding the medical conditions observed in such population [11].

Another Spanish study on immigrants arriving by sea at southern Spain, during 2016, notices a higher prevalence of health issues on immigrants from Sub-Saharan Africa as compared to the ones from Maghreb countries, mainly attributed to the higher duration of their travel and thereby prolonged exposure of themselves to harsh conditions [12]. Cañardo et al. [13], operating with the non-governmental organization (NGO) Open Arms, agree on the fact that the majority of the population up until 2018 originated from Sub-Saharan countries and that their health status appeared to be directly linked to the poor and precarious living conditions in transit [13]. Again skin, respiratory and gastrointestinal tract appeared to be the organs mostly affected. Something not quite noted on previous studies is the fact that they recorded a very low percentage of non-communicable diseases, either due to the younger mean age of those travelling or due to the realisation that such a long and dangerous journey can be undertaken from the more robust part of the migrant community. Their assumption does not agree with a study by Shortall et al. [14] performed on migrants arriving in Greece, where it is explained that mass displacement results in prioritising basic needs, thus leaving chronic non-communicable diseases undertreated and therefore with higher severity scores and complication rates [14]. Open Arms's study highlights also the vulnerability among the woman population traveling, with a $12 \%$ among them being pregnant but with unfortunately no proper antenatal care.
Angeletti et al. [15] appears to be the most thorough, in terms of analysing communicable diseases among such populations. Specific interview for tuberculosis, Mantoux skin test, X-ray and blood screening were some of the tests carried out on a land bound reception centre in Italy. Again from their study one can easily deduct the low prevalence of transmissible disease but the extreme deterioration on the nutritional and vitamin status of the migrant population. For one thing we can be sure, the majority of the migrants leave their country of origin in overall good health, so it is the journey and the precarious living conditions during it that cause a significant burden both physically and psychologically (Table 3) [15].

\section{B. ORGANIZING MEDICAL SUPPORT - MEDICAL EQUIPMENT AND PREPAREDNESS}

Bearing in mind the above analysis regarding the consistency of the population in distress at sea, several papers offer insight on how a medical team needs to be organized on board as well as how to perform correctly a SAR operation through medical perspective. Vessel adjustments and proper crew formation seems to be of crucial importance $[2,8,9,16]$. According to Dittman et al. [2] the flight deck of a rescue boat needs to be divided to three areas, one for those rescued, one for those requiring medical attention and one with toilets and washing facilities. Rescuing from the water was performed through two life rafts after the proper implementation of personal protective equipment (PPE) by the rescuers. The occurrence of vermin along with the possibility of infectious diseases, mostly due to overcrowding and poor hygiene conditions seems to be avoided by the use of protective measures and the disposal of contaminated clothing $[2,9,10]$. PPE with protective respiratory masks and googles is also recommended by Kulla et al. [8] as basic form of crew's protection during rescue missions along with the installation of double door systems between the ship's divided areas. Another instruction is the preparation of different areas of the ship for security check, medical triage, first assistance, emergency assistance, isolation, obstetric emergencies, outpatient consultation, and accommodation of vulnerable groups [17].

The majority of the studies agree on the presence of an emergency physician, a nurse and a midwife, along with a psychologist, a humanitarian officer and a cultural mediator as the minimum prerequisite for safe and successful SAR operations [2, 8, 9, 16, 17]. Doctors need to be trained on handling emergency situations up until disembarkation. Additional knowledge on emergency evacuation (MEDEVAC) either by boat or helicopter, and training in the use of radio-communication seems necessary as quite often medical consultations and arrangements for severe cases are performed through the radio with land-bound services $[16,18]$. 
Table 3. Summary of search and rescue studies showing basic demographic and medical information regarding rescued migrants (on each category, data with the higher percentages will be presented)

\begin{tabular}{|c|c|c|c|c|c|}
\hline Study author & Year & $\begin{array}{l}\text { Origin of rescued } \\
\text { migrants }\end{array}$ & Age group & $\begin{array}{l}\text { Non communicable } \\
\text { diseases }\end{array}$ & $\begin{array}{l}\text { Communicable } \\
\text { diseases }\end{array}$ \\
\hline Trovato et al. & 2014 & $\begin{array}{l}\text { Syria } 37 \% \\
\text { Gambia } 10 \% \\
\text { Eritrea } 10 \%\end{array}$ & $\begin{array}{l}\text { Adults } 78 \% \\
\text { (81\% males) }\end{array}$ & $\begin{array}{l}\text { Respiratory } 21 \% \\
\text { Dermatological } 20 \% \\
\text { Trauma } 12 \% \\
\text { Presence of chronic } \\
\text { disease } 11 \%\end{array}$ & $\begin{array}{l}\text { No clinical suspicion of } \\
\text { tuberculosis } 99 \%\end{array}$ \\
\hline Kulla et al. & 2016 & Not mentioned & $\begin{array}{l}\text { Adults } 88.5 \% \\
(77.1 \% \text { males })\end{array}$ & $\begin{array}{l}\text { Dermatological } 55.4 \% \\
\text { Cardiovascular } 22.1 \% \\
\text { Trauma } 7.6 \%\end{array}$ & $\begin{array}{l}\text { Gastrointestinal } \\
\text { infection } 1.1 \%\end{array}$ \\
\hline Escobio et al. & 2016 & $\begin{array}{l}\text { Gambia } 27.8 \% \\
\text { Nigeria } 24.1 \% \\
\text { Senegal } 11.8 \%\end{array}$ & Male minors $43.6 \%$ & $\begin{array}{l}\text { Accidental trauma } 24.1 \% \\
(52.9 \% \text { chemical burn due } \\
\text { to benzene) } \\
\text { Medically unexplained } \\
\text { physical symptoms } 14.2 \% \\
\text { Intentional trauma } 6.6 \% \\
\text { ( } 50 \% \text { contusions) }\end{array}$ & $\begin{array}{l}\text { Gastrointestinal } \\
\text { problems } 6.6 \%\end{array}$ \\
\hline $\begin{array}{l}\text { Ponce-Blandón } \\
\text { et al. }\end{array}$ & 2016 & $\begin{array}{l}\text { Sub-Saharan Africa } \\
53.1 \% \\
\text { Maghreb } 46.2 \%\end{array}$ & $\begin{array}{l}18-40 \text { years } 70.5 \% \\
91.2 \% \text { males }\end{array}$ & $\begin{array}{l}\text { Dermatological } 24.7 \% \\
\text { Gynaecological } 21.1 \% \\
\text { Headache } 15.6 \%\end{array}$ & $\begin{array}{l}\text { Respiratory tract } 6.4 \% \\
\text { Gastrointestinal } 5.5 \%\end{array}$ \\
\hline Shortall et al. & 2015 & $\begin{array}{l}\text { Syria } 46.2 \% \\
\text { Afghanistan } 29 \% \\
\text { Iraq } 12.3 \%\end{array}$ & Not clarified & $\begin{array}{l}40 \% \text { non-communicable } \\
\text { disease }\end{array}$ & $\begin{array}{l}\text { Mostly respiratory } \\
\text { infections } \\
\text { and diarrhoea }\end{array}$ \\
\hline Cañardo et al. & $\begin{array}{l}2016- \\
-2018\end{array}$ & $\begin{array}{l}\text { Sub-Saharan Africa } \\
74.3 \% \\
\text { Asia } 14.7 \% \\
\text { Northern Africa } 11.1 \%\end{array}$ & $\begin{array}{l}\text { Mean age rescues } \\
19.9 \text { years } \\
15.1 \% \text { women } \\
\text { ( } 11 \% \text { of them pregnant) }\end{array}$ & $\begin{array}{l}\text { Hypothermia } 5.8 \% \\
\text { Acute injury } 3 \%\end{array}$ & $\begin{array}{l}\text { Infectious diseases } \\
42 \% \text { (the majority } \\
\text { scabies } 8.2 \% \text { ) }\end{array}$ \\
\hline Angeletti et al. & 2018 & Eritrea 100\% & $\begin{array}{l}92 \% \text { males } \\
\text { Median age } 24 \text { years }\end{array}$ & $\begin{array}{l}\text { Malnutrition } \\
\text { Vitamin D deficiency }\end{array}$ & $\begin{array}{l}15.8 \% \text { with suspected } \\
\text { transmissible disease- } \\
\text {-only } 10 \% \text { among them } \\
\text { with tuberculosis or } \\
\text { pneumonia }\end{array}$ \\
\hline
\end{tabular}

Initial assessment during SAR operations is being highlighted as completely different from the one performed in a hospital Accident and Emergency department (A\&E). All the studies agree that the rescue crew is bound to face a huge workload under stressful and harsh conditions. Limited amount of time can be allowed per rescued person both due to confined space and continuous influx [8]. The possibility of a backlog would jeopardize the whole rescue procedure, thus fast triage systems need to be implemented by experienced and trained personnel. Different triage systems were observed in the studies. Escobio et al. [9] preferred the South African Triage Scale (SATS) system, while Jachetti et al. [17] the Simple Triage and Rapid Treatment (START), the German SAR first responder course presents its own algorithm based on checking consciousness, respiration and pulse rate [16] and Kulla et al. [8] established also their own pattern of response. According to them, after registration and documentation, a series of technical examinations (core body temperature, pulse rate and peripheral oxygen saturation) preceded initial assessment which included the ability to walk, pattern of ventilation and pulse rate [8]. Cañardo et al. [13] also prioritized registration upon transferring migrants from the initial boat and they also utilise saturation and core temperature during medical assessment. The majority of the studies during initial medical assessment share the same purpose of allocating the injured and the supplies in an efficient way, allowing proper management of all those the crew's medical personnel can attend to, while organizing proper evacuation procedures in time for the severe cases (Table 4).

Having reviewed on the sections above the origin, the age groups and the medical conditions from which suffer the majority of those rescued, one can easily organize the infrastructure needed on board.

Customisation of a boat's areas simulating a hospital environment with basic emergency tools like an automated external defibrillator, equipment for airway 
Table 4. Triage systems preferred by each study

\begin{tabular}{ll}
\hline Study author & Triage system preferred \\
\hline Escobio et al. & South African Triage Scale (SATS) triage \\
Jachetti et al. & Simple Triage and Rapid Treatment (START) triage \\
Cañardo et al. & $\begin{array}{l}\text { Documentation and registration first } \\
\text { System based on ventilation, core temperature, oxygen saturation, skin integrity, pulse rate }\end{array}$ \\
Kulla et al. & $\begin{array}{l}\text { Documentation and registration first } \\
\text { System based on ventilation, core temperature, pulse rate, oxygen saturation, walking ability } \\
\text { Buschmann et al. }\end{array}$ \\
& $\begin{array}{l}\text { System based on consciousness, respiration and pulse rate } \\
\text { Documentation later on }\end{array}$
\end{tabular}

management (all sizes of endotracheal tubes and supraglottic devices, laryngoscopes), for oxygen delivery and for managing blood or fluid loss, is being described both by the German SAR programme and by Jachetti on board Prudence with the MsF team $[16,17]$. The presence of old infected wounds, lacerations and even oropharyngeal abscesses that often need debriding, cleaning and stitching demonstrates the need for basic surgical instruments, antibiotics as well as disinfectants [8]. The German SAR educational programme lists several drugs needed on board [16]. Zamatto et al. [19] highlight also the increased presence of fuel burns on those rescued by sea. It consists of a chemical burn caused by the mixture of gasoline, leaked from a boat's container, and salt water. The combination results in third degree erosive burns that require special management in terms of everyday care, analgesia and antibiotic prophylaxis.

Provisions should be made for adequate food and water supplies both for the ship's crew and the population rescued, taking into account that:

- a large number of persons are usually rescued through each operation;

- people rescued have suffered travelling for a long time through land and sea without proper nourishment and hydration;

- delays can occur while arranging disembarkation with the RCCs involved [20].

Women and children on board call for special attention, therefore special management plans. A midwife with a set for delivery if deemed necessary, along with equipment dedicated to newborn care should be included on a well-coordinated SAR operation [17].

Traumatic events during the travel call for the presence of a psychologist so as to give the rescued a chance of handling his or her anxiety and mental burden besides common medications $[9,17]$. A translator's presence, with more than one language translating capacity, would ease both the anxiety of the rescued and the workload of the rescuers (Tables 5, 6) $[8,9,17]$.
Table 5. List of medical equipment and personnel needed on board search and rescue vessels

Automated external defibrillator
Airway management equipment (SADs, intubation kits,
AMBU masks)
Oxygen delivery systems and ventilator
Fluid resuscitation systems
Kits for wound disinfection and debriding (sutures, antibiotics,
gauzes etc.)
Essential drugs (for cardiovascular resuscitation, for analgesia,
antibiotics etc.)
Equipment for emergency delivery during obstetric emergencies
Equipment for neonatal and paediatric support
Immobilisation and transport equipment
Personal protective equipment and disinfectants
Diagnostic methods: electrocardiogram, glucometer, ultrasound,
urine test strips, rapid malaria tests
Large numbers of water and nutritional supplies
Thermal blankets
Personnel: midwife, translator; doctor trained in handling
emergencies (both adult, paediatric and obstetric),
trained in performing MEDEVAC

\section{OPERATIONAL GUIDELINES FOR SAR DURING THE COVID-19 ERA}

Understanding that the main priority for SAR organizations is firstly to protect the personnel involved during the rescue and secondly to provide adequate and high quality SAR and lifesaving services, has led to the adaptation of specific guidelines for SAR provision during the COVID-19 pandemic [21].

Such a challenging public health issue requires high levels of coordination among maritime service providers and port states to protect both seafarer's and general public's health [22]. Recommendations cover a wide range of activities, from personnel training on recognising suspected cases, donning and doffing PPE, disinfecting and disposing 
Table 6. Recent examples of search and rescue vessels and their characteristics, data available from: http://searchandrescue.msf. org/, https://sea-watch.org/en/mission/sea-watch-4/, https://onboard.sosmediterranee.org/our-mission/

\begin{tabular}{|c|c|c|c|c|c|c|}
\hline $\begin{array}{l}\text { Vessel } \\
\text { name }\end{array}$ & Year & $\begin{array}{l}\text { Non-governmen- } \\
\text { tal organizations } \\
\text { name }\end{array}$ & $\begin{array}{l}\text { Vessel and } \\
\text { crew size }\end{array}$ & Vessel capacity & $\begin{array}{l}\text { Vessel medical } \\
\text { equipment }\end{array}$ & $\begin{array}{l}\text { Vessel additional rescue } \\
\text { boats }\end{array}$ \\
\hline $\begin{array}{l}\text { Ocean } \\
\text { Viking }\end{array}$ & 2019 & $\begin{array}{l}\text { MsF, Sos Mediter- } \\
\text { rané }\end{array}$ & $\begin{array}{l}69 \mathrm{~m} \text { long, } \\
15.5 \mathrm{~m} \text { long }\end{array}$ & Up to 200 survivors & $\begin{array}{l}\text { Medical clinic with } \\
\text { consultation, triage } \\
\text { and recovery rooms }\end{array}$ & $\begin{array}{l}\text { One davit-launched fast } \\
\text { rescue craft } \\
\text { Two davit-launched fast } \\
\text { rescue boats } \\
\text { One crane-launched fast } \\
\text { rescue boat } \\
\text { One inflatable rescue boat }\end{array}$ \\
\hline Astral & 2019 & $\begin{array}{l}\text { Proactiva Open } \\
\text { Arms }\end{array}$ & $30 \mathrm{~m}$ long & Unavailable & Unavailable & Unavailable \\
\hline $\begin{array}{l}\text { Sea } \\
\text { Watch } 3\end{array}$ & $\begin{array}{l}2019- \\
-2020\end{array}$ & Sea-Watch & $55 \mathrm{~m}$ long & Unavailable & Unavailable & Unavailable \\
\hline $\begin{array}{l}\text { Sea } \\
\text { Watch } 4\end{array}$ & $\begin{array}{l}2019- \\
-2020\end{array}$ & Sea-Watch, MsF & $\begin{array}{l}60.8 \mathrm{~m} \text { long, } \\
\text { up to } 26 \mathrm{crew} \\
\text { members }\end{array}$ & $\begin{array}{l}300 \text { survivors, } 900 \\
\text { survivors during } \\
\text { emergencies for } \\
\text { a short time }\end{array}$ & $\begin{array}{l}\text { Extra safe area for } \\
\text { women and children } \\
\text { with } 24 \text { beds }\end{array}$ & Unavailable \\
\hline
\end{tabular}

waste, to deck adaptations in order to allow isolation of possibly infected seafarers [21-24].

More specifically frequent and proper hand hygiene, distancing of at least 2 metres among crew members, disposable gloves, face touching avoidance during work, infection control coveralls and safety googles or face shields are measures and equipment considered absolutely necessary on board all rescue vessels [21, 22, 25]. Suspected cases on board should be isolated on a specially designated location, and a limited number of crew members - with fully donned PPE - should be responsible for handling them in an effort to minimise crew exposure. In terms of decontamination, all possibly soiled surfaces should be disinfected starting from cleaner areas towards dirtier ones, from higher ground towards lower surfaces $[21,22]$. A routine of pre-cleaning followed by the application of high-grade disinfectants both at surfaces and objects is recommended [21]. Caution should be given towards waste as they are all considered infectious substances and should be packaged accordingly for disposal. The most common types of waste include face masks, gloves, infection coverage suits, food packaging and utensils. Everything that comes in contact with a potentially infected person will be considered a Category A infectious substance, thus requires specialized handling according to national guidelines [21].

As seafarers remain key workers required to travel across borders at all times, the need for presenting a proof of COVID-19 vaccination as a condition for entry in some countries, arose. Although World Heart Organization (WHO) recommended against such certificates for international travel, proof of vaccination has started to become a prerequisite. In
March 2021, the International Maritime Organization (IMO) urged governments to consider seafarers part of the essential workforce that should be granted priority in COVID-19 national vaccination programmes [26], in compliance with the WHO SAGE Roadmap that mentions the need for prioritising vaccine use in the context of limited supply [27].

What appears to be worth analysing are the adaptations regarding resuscitation both in terms of providing cardiopulmonary resuscitation (CPR) and specifically ventilation to those unconscious. Mitigating infection risk during resuscitation requires rescuers to attempt an identification of suspected cases among those in risk of drowning. Everyone can agree that this is an unrealistic goal in the conditions described so far during SAR operations in the Mediterranean [24]. The International Maritime Rescue Federation (IMRF), the International Drowning Researcher's Alliance (IDRA), the International Life Saving Federation-Medical Committee (ILS-MC) and the International Chamber of Shipping as well as national Coast Guards like the Canadian Coast Guard, since April 2020, have attempted to provide providers of SAR with some advisory measures, specifically adapted to the COVID-19 context. It is discussed that a drowned person should be treated as potentially infectious if they appear to have COVID-related symptoms, or when close contacts also present with symptoms. Resuscitation cannot start unless adequate PPE is donned. It remains controversial whether or not to resuscitate if survival chances appear to be low or futile for persons with unknown COVID-19 status. IDRA suggests that prolonged submersion time, prolonged time before the start of resuscitation, and prolonged time to arrival of advanced care are all poor prognostic factors; however, there is no real cut-off point in time that rescuers can adhere to [24]. 
Table 7. Non-governmental organizations ships involved in search and rescue operations in the Mediterranean Sea between 2016 and June 2020

\begin{tabular}{|c|c|c|c|}
\hline $\begin{array}{l}\text { Operational (data } \\
\text { until June 2020) }\end{array}$ & $\begin{array}{l}\text { Legal proceedings against } \\
\text { vessel/crew }\end{array}$ & $\begin{array}{l}\text { At port due to } \\
\text { COVID-19/maintenance }\end{array}$ & Not operational before 1/6/2020 \\
\hline $\begin{array}{l}\text { Astral, Mare Jonio, } \\
\text { Moonbird, Sea Watch } 3\end{array}$ & $\begin{array}{l}\text { The Sea eye, Aquarius, Seefuchs, Golfo } \\
\text { Azurro, Vos Hestia, Vos Prudence, Mare } \\
\text { Liberum, Open Arms, Moonbird, Sea } \\
\text { Watch 3, Mare Jonio, Josefa, Aita mari, } \\
\text { Alan Kurdi, luventa, Lifeline, Eleonore }\end{array}$ & $\begin{array}{l}\text { Ocean Viking, Open Arms, } \\
\text { Sea Watch 4, Seabird, } \\
\text { Josefa, Mare Liberum }\end{array}$ & $\begin{array}{l}\text { The Sea eye, Aquarius, Seefuchs, Golfo } \\
\text { Azurro, Vos Hestia, Vos Prudence, Pho- } \\
\text { enix, Minden, Sea Watch, Sea Watch 2, } \\
\text { Bourbon Argos, Dignity 1, Aita Mari, } \\
\text { Alan Kurdi, luventa, Eleonore, Lifeline }\end{array}$ \\
\hline
\end{tabular}

Once resuscitation has been decided upon, measures such as positioning the drowned downward from the rescuer and deploying rescuers belonging to lower risk groups in terms of age and comorbidities are some mitigation risk strategies. However it must be understood that the possibility to become infected (and spread the virus) will remain present [24]. As far as the CPR procedure is concerned, performing ventilations is the most difficult and controversial element among recommendations. The International Liaison Committee on Resuscitation (ILCOR) states that most unconscious persons are not to be ventilated, with the exception of children, as an effort to reduce exposure among laypersons. When proper PPE is available, when the likelihood of infection is low, when the drowned is a child or when a close contact of the person that is unconscious is present, trained and willing to provide ventilations, then ventilations are still considered the best practice. The practice of mouth-to-mouth/nose ventilations without any barrier device should be abandoned. Three techniques have been identified as the most adequate during the COVID-19 era:

- two rescuer bag-mask-ventilation with HEPA filter (BVM);

- mouth-to-mask ventilation with HEPA filter;

- passive oxygenation.

One can realise that many organizations and individuals will struggle to obtain the adequate types of PPE and other equipment recommended for resuscitating drowning persons during the COVID-19 pandemic. They may not have access to the training necessary to use this equipment safely and effectively. Suspended operations due to logistic difficulties caused by the coronavirus pandemic appears to be the norm among NGO SAR vessels [28]. State governments, like Italy and Malta, have introduced national and local restrictions, including: delayed port clearance, prevention of crew (or passengers where applicable) from embarking or disembarking, imposition of quarantine or refusal of port entry to ships [22]. However, one cannot forget that according to all the relevant international conventions, even during the ongoing COVID-19 outbreak, the effective protection of the health and safety of all seafarers must remain a priority. More specifically the International Labour Organization (ILO) Maritime Labour Convention highlights the need of port states to ensure the immediate medical care on land bound facilities to any seafarer on board ships in their territory, as treating infectious cases on board could endanger others [29].

\section{MEDICO-LEGAL IMPLICATIONS OF SAR ACTIVITIES}

European efforts in handling the Mediterranean migrational wave from 2014 up until nowadays include different operations and organizational patterns. From operation "Mare Nostrum" led by the Italian government during 2014, responsible for the rescue of nearly 150,000 migrant lives, EU progressively decided on aiming more at border control rather than proactive SAR operations by implementing operations "Triton" (during 2015) and "Sophia" (from 2015 until now, through different phases). Operating closer to Italian coast, these operations prioritise apprehending smugglers making secondary contributions to SAR resulting to an increased death rate in the region after their implementation [30]. The gradual withdrawal of EU-led operations, inaugurated the larger involvement of humanitarian NGOs in search and rescue operations from 2015 up until now (Table 7).

From the table above one can understand that the described shift from state-led operations towards NGO's involvement in SAR was accompanied by a significant increase in the criminalisation of humanitarian volunteers involved. Arguments regarding SAR operations as a "pull" factor for the increased influx of migrants through the Mediterranean and as a reason why smugglers use less sea-worthy means of travel, thus further endangering migrant lives, are being widely used by EU countries as an excuse to legally persecute those who have been aiding migrants in distress [30, 31]. Founding their legal basis on the 2002 EU Facilitation Directive and Framework, that fails to distinguish between smuggling and humanitarian assistance, EU countries utilise criminalisation as a mean to deter and shield their borders from irregular immigration [31].

Apart from the obvious unethical aspect of allowing people to drown in the name of their own security and as a way to deter others, it is international law along with United Nations legislation that highlights the obligation of states to 
rescue, or facilitate the rescue of people in distress at sea [31]. As the right to life prevails upon national legislation, subsequently efforts to preserve it should not be able to be criminalised.

In terms of responding to the unfounded accusations against NGO-led SAR operations, a paper by Arsenijevic et al. [30] manages to refute them. They claim that such allegations fail to take into consideration the complexity of migration dynamics and drivers such as conflict, prosecution and poverty. Their statistics provide proof that NGO involvement after EU withdrawal from SAR resulted in the saving of 46,806 people in total, with a $59 \%$ improvement of maritime safety as depicted by the reduction of adverse sea outcomes [30]. In the meantime scaling back from SAR, since 2019, contributed to a higher mortality rate among those travelling and led to a preference of longer and riskier routes in the Mediterranean, fact that entails a safety decline.

\section{WHAT IS DICTATED BY LAW?}

Providing assistance to any person in distress at sea is a clear legal requirement under international maritime law [1, 20]. International conventions concerning sea rescue include:

- the 1982 United Nations Convention of the Law of the Sea (UNCLOS);

- the 1974 International Convention for the Safety of Life at Sea (SOLAS) by the IMO;

- the 1979 International Convention on Maritime Search and Rescue by the IMO.

According to UNCLOS and SOLAS it is a ship master's obligation to render assistance to all those in distress at sea without regard to their nationality, status or circumstances in which they are found, even if the distress situation was caused on purpose [2]. SAR convention obliges all coastal states to implement specific search and rescue zones (SAR zones), each with a maritime RCC in charge of accepting responsibility for all rescue efforts in their region. They are the ones that would organize and coordinate assisting ships up until disembarkation to a place of safety. IMO states that a place of safety is where rescue operations are terminated while a person's safety of life is no longer threatened and basic human needs are met, highlighting that it has to be a place with no immediate danger of prosecution, incarceration or torture [1, 3, 20, 32, 33]. International asylum and migration law also clearly states that state agencies (ex. coast-guard vessels) have direct obligation not to engage in or allow refoulement [1]. Although definition of distress remains vague, it is the rescue ship's captain who will make an assessment of the situation [33]. With the sea being a dangerous environment for people and the majority of the boats being overloaded and not seaworthy, nearly all cases are considered under distress even from the moment they launch $[19,33]$.

\section{CONCLUSIONS}

We conclude that during rescue medical activities in the Mediterranean specific qualification adapted to maritime search and rescue appears to contribute in better quality healthcare services. Previous understanding of the population at risk and the concomitant comorbidities, along with rescue ship adjustments with adequate equipment constitute an integral part of a physician's preparedness training. Health care providers should maintain a high level of emergency skills along with a situational awareness based on understanding the legal framework upon which they will operate. Coordination among state and military agencies and NGO vessels is proven to be frequently difficult due to different goal settings, resulting in miscommunication and additional stress for which all personnel involved needs to be prepared. We want to emphasize the fact that an ongoing human tragedy is being unfolded in the Mediterranean Sea, for which EU gradually chooses a "non-assistance" response. A higher level of proactive SAR operations with more rescue assets is in our view the only adequate response, secondary to ensuring safe routes to those fleeing war and poverty. Therefore health care workers choosing to participate in SAR missions should operate with the imperative to save lives as the only way to respect international legal obligations and human values.

\section{REFERENCES}

1. Remøy M. At sea a guide to principles and practice as applied to refugees and migrants. 16.

2. Dittmann F, Dirksen-Fischer M, Harth V, et al. The rescue of refugees: a challenge for the merchant fleet. Int Marit Health. 2015; 66(4): 252-257, doi: 10.5603/IMH.2015.0047, indexed in Pubmed: 26726897.

3. FACT BOX Italy: The rescue system from SOS to arrival at port - InfoMigrants [Internet]. https://www.infomigrants.net/en/post/10191/ fact-box-italy-the-rescue-system-from-sos-to-arrival-at-port (cited 2020 Mar 20).

4. Central Mediterranean Route [Internet]. https://frontex.europa.eu/ along-eu-borders/migratory-routes/central-mediterranean-route/ (cited 2020 Apr 12).

5. Central Mediterranean Sea Initiative [Internet]. https://www.unhcr. org/542c07e39.pdf (cited 2020 Apr 12).

6. Aita R. Briefing Series: Towards safer migration in Africa: Migration and Data in Northern and Western Africa CALCULATING "DEATH RATES" IN THE CONTEXT OF MIGRATION JOURNEYS: Focus on the Central Mediterranean. 12.

7. Refugees UNHC for. Refworld | Communication from the Commission to the European Parliament, the European Council and the Council: Next operational steps in EU-Turkey cooperation in the field of migration [Internet]. Refworld. https://www.refworld.org/ docid/56e988a14.html (cited 2021 Mar 16).

8. Kulla M, Josse F, Stierholz M, et al. Initial assessment and treatment of refugees in the Mediterranean Sea (a secondary data analysis concerning the initial assessment and treatment of 2656 refugees rescued from distress at sea in support of the EUNAVFOR MED relief mission of the EU). Scand J Trauma Resusc Emerg Med. 2016; 
24: 75, doi: 10.1186/s13049-016-0270-z, indexed in Pubmed: 27206483

9. Escobio F, Etiennoul M, Spindola S. Rescue medical activities in the mediterranean migrant crisis. Confl Health. 2017; 11: 3, doi: 10.1186/s13031-017-0105-1, indexed in Pubmed: 28344642.

10. Trovato A, Reid A, Takarinda KC, et al. Dangerous crossing: demographic and clinical features of rescued sea migrants seen in 2014 at an outpatient clinic at Augusta Harbor, Italy. Confl Health. 2016; 10: 14 , doi: 10.1186/s13031-016-0080-y, indexed in Pubmed: 27307789.

11. Jiménez-Lasserrotte MD, López-Domene E, Fernández-Sola C, et al. Accompanied child irregular migrants who arrive to Spain in small boats: Experiences and health needs. Glob Public Health. 2020; 15(3): 345-357, doi: 10.1080/17441692.2019.1665083, indexed in Pubmed: 31516078.

12. Ponce-Blandón JA, Mérida-Martín T, Jiménez-Lasserrotte MD, et al. Analysis of Prehospital Care of Migrants Who Arrive Intermittently at the Coasts of Southern Spain. Int J Environ Res Public Health. 2020; 17(6), doi: 10.3390/ijerph17061964, indexed in Pubmed: 32192156.

13. Cañardo G, Gálvez J, Jiménez J, et al. Health status of rescued people by the NGO Open Arms in response to the refugee crisis in the Mediterranean Sea. Confl Health. 2020; 14: 21, doi: 10.1186/ s13031-020-00275-z, indexed in Pubmed: 32377233.

14. Shortall CK, Glazik R, Sornum A, et al. On the ferries: the unmet health care needs of transiting refugees in Greece. Int Health. 2017; 9(5): 272-280, doi: 10.1093/inthealth/ihx032, indexed in Pubmed: 28911130.

15. Angeletti S, Ceccarelli G, Bazzardi R, et al. Migrants rescued on the Mediterranean Sea route: nutritional, psychological status and infectious disease control. J Infect Dev Ctries. 2020; 14(5): 454-462, doi: 10.3855/jidc.11918, indexed in Pubmed: 32525831

16. Buschmann C, Niebuhr N, Schulz T, et al. "SAR-First-Responder Sea" - backgrounds to a medical education concept in German SAR service. Int Marit Health. 2009; 60(1-2): 43-47, indexed in Pubmed: 20205128.

17. Search and Rescue Operations at Sea: The perspective of a young emergency physician [Internet]. https://eusem.org/images/ Pre0029-Jachetti_Alessandro.pdf (cited 2020 Apr 10).

18. Ricci G, Pirillo I, Rinuncini C, et al. Medical assistance at the sea: legal and medico-legal problems. Int Marit Health. 2014; 65(4): 205-209, doi: 10.5603/IMH.2014.0039, indexed in Pubmed: 25522704.

19. Zamatto F, Argenziano S, Arsenijevic J, et al. Migrants caught between tides and politics in the Mediterranean: an imperative for search and rescue at sea? BMJ Glob Health. 2017; 2(3): e000450, doi: 10.1136/ bmjgh-2017-000450, indexed in Pubmed: 29225947.

20. Large Scale Rescue Operations at Sea [Internet]. https://www. ics-shipping.org/docs/default-source/refugee-migrant-rescue/ large-scale-rescue-operations-at-sea33E6D8E4E3B2.pdf?sfvrsn=0 (cited 2020 Apr 15).

21. Laing A. IMRF COVID-19 Operational Guidelines 28 April 2020. 2020;23.

22. covid19-guidance-for-ship-operators-for-the-protection-of-the-healthof-seafarers-v3-min.pdf [Internet]. https://www.ics-shipping.org/ wp-content/uploads/2020/11/covid19-guidance-for-ship-operators-for-the-protection-of-the-health-of-seafarers-v3-min.pdf (cited 2020 Dec 23).

23. Government of Canada CCG. 502 COVID-19 - Instructions for Rescue Specialist in Assisting a Suspected COVID-19 Patient [Internet]. 2019. https://www.ccg-gcc.gc.ca/publications/NSOP-PONEN/502eng.html?wbdisable=true (cited 2020 Dec 23).

24. IDRA-ILS-IMRF: COVID-19 Drowning Resuscitation Guidance Published [Internet]. International Maritime Rescue Federation. https://www.international-maritime-rescue.org/News/idra-ils-imrf-covid-19-drowning-resuscitation-guidance-published (cited 2020 Dec 24).

25. Circular Letter No.4204-Add.23 - Coronavirus (Covid-19) - Recommendations For Port And CoastalStates On medical care.pdf [Internet]. https://wwwcdn.imo.org/localresources/en/MediaCentre/HotTopics/Documents/COVID\%20CL\%204204\%20adds/ Circular\%20Letter\%20No.4204-Add.23\%20-\%20Coronavirus\%20 (Covid-19)\%20-\%20Recommendations\%20For\%20Port\%20And\%20 CoastalStates\%200n\%20medical\%20care.pdf (cited 2021 Apr 3).

26. Circular Letter No.4204-Add.38 - Coronavirus (Covid-19) - Joint Statement Calling On All GovernmentsTo Prioritize Covid-19... (Secretariat).pdf [Internet]. https://wwwcdn.imo.org/localresources/en/ MediaCentre/HotTopics/Documents/COVID\%20CL\%204204\%20 adds/Circular\%20Letter\%20No.4204-Add.38\%20-\%20Coronavirus\%20(Covid-19)\%20-\%20Joint\%20Statement\%20Calling\%20 On\%20All\%20GovernmentsTo\%20Prioritize\%20Covid-19...\%20 (Secretariat).pdf (cited 2021 Apr 3).

27. WHO SAGE Roadmap For Prioritizing Uses Of COVID-19 Vaccines In The Context Of Limited Supply [Internet]. (https://www.who.int/publications/m/item/who-sage-roadmap-for-prioritizing-uses-of-covid19-vaccines-in-the-context-of-limited-supply) (cited 2021 Apr 3).

28. How coronavirus hits migrants and asylum seekers in Italy [Internet]. The New Humanitarian. 2020. https://www.thenewhumanitarian. org/news/2020/03/16/italy-coronavirus-migrants-asylum-seekers (cited 2020 Dec 24).

29. Bergmeijer P. The international convention for the prevention of pollution from ships. Ports As Nodal Points in a Global Transport System. 1992: 259-270, doi: 10.1016/b978-0-08-040994-8.50026-7.

30. Arsenijevic J, Manzi M, Zachariah R. Are dedicated and proactive search and rescue operations at sea a "pull factor" for migration and do they deteriorate maritime safety in the central Mediterranean? 21.

31. Gordon E, Larsen HK. 'Sea of blood': the intended and unintended effects of the criminalisation of humanitarian volunteers rescuing migrants in distress at sea. Disasters. 2020 [Epub ahead of print], doi: 10.1111/disa.12472, indexed in Pubmed: 33314260.

32. Can the Law of the Sea regulate the stormy standoffs between private rescue ships and EU governments? - InfoMigrants [Internet]. https://www.infomigrants.net/en/post/18037/can-the-law-ofthe-sea-regulate-the-stormy-standoffs-between-private-rescueships-and-eu-governments (cited 2020 Mar 20).

33. Sea rescue - what the law says [Internet]. InfoMigrants. 2019. https://www.infomigrants.net/en/post/21314/sea-rescue-whatthe-law-says (cited 2020 Mar 2). 